\title{
FACTORS INFLUENCING SUCCESSFUL IMPLEMENTATION OF ENHANCED OIL RECOVERY PROJECTS
}

\section{FAKTORI OD UTICAJA NA USPEŠNOST REALIZACIJE PROJEKTA POVEĆANJA ISKORIŠĆENJA NAFTNIH LEŽIŠTA}

\author{
Karović Maričić Vesna ${ }^{1}$, Leković Branko ${ }^{1}$, Danilović Dušan ${ }^{1}$
}

Received: November 24, 2014

Accepted: December 15, 2014

\begin{abstract}
Tertiary methods in oil production process called 'Enhanced Oil recovery methods' (EOR) are mostly applied in mature oil fields with declining production trend after primary and secondary recovery methods or immediately after primary production phase. These 'Enhanced Oil Recovery' methods implies injection of gases or fluids to mobilize residual oil captured in reservoir rock due to presence of strong viscous and capillary forces and high value of interfacial tension between fluid and rock. Depending on the type of injected fluid, production mechanism, as well as an approach to implementation, EOR methods are divided into thermal methods, chemical methods, miscible/immiscible gas injection methods and other methods that so far have an experimental application. The paper analyzes the key factors influencing the successful implementation of EOR projects: phases of EOR project implementation, the price of crude oil at the world market as a criterion for the beginning and the justification for EOR process application and development of new technologies for more efficient process realization.
\end{abstract}

Key words: enhanced oil recovery project, influential key factors, successful implementation

Apstrakt: Tercijarne metode procesa iskorišćenja naftnh ležišta, odnosno metode povećanja iskorišćenja naftnih ležišta ("EOR" metode) primenjuju se kod ležišta dugog eksploatabilnog veka i opadajućim proizvodnim trendom posle primene primarnih i sekundarnih metoda iskorišćenja ili neposredno nakon primarne faze. Ove metode podrazumevaju utiskivanje gasovitih ili tečnih fluida u cilju ostvarivanja kretanja preostalih količina nafte zarobljenih u pornom prostoru rezervoar stena usled prisustva jakih viskoznih i kapilarnih sila, kao i visoke vrednosti međufaznog napona između fluida i stene. $U$ zavisnosti od tipa injektiranog fluida, proizvodnih mehanizama, kao i pristupa realizaciji procesa, izvršena je klasifikacija "EOR" metoda na: termičke metode, hemijske metode, metode utiskivanja gasova u uslovima mešanja/nemešanja i ostale metode sa eksperimentalnom primenom.

\footnotetext{
${ }^{1}$ University of Belgrade - Faculty of Mining and Geology, Đušina 7, 11000 Belgrade, Serbia, e-mails: vesna.karovic@rgf.bg.ac.rs; branko.lekovic@rgf.bg.ac.rs; dusan.danilovic@rgf.bg.ac.rs
} 
U radu se analiziraju faktori od ključnog uticaja na uspešnost implementacije projekata povećanja iskorišćenja naftnih ležišta: faze realizacije projekta, cena nafte na svetskom tržištu kao osnovni kriterijum opravdanosti primene EOR metoda, kao i primena i razvoj novih tehnologija za efikasniju realizaciju procesa.

Ključne reči: projekat povećanja iskorišćenja naftnih ležišta, ključni faktori, uspešnost realizacije

\section{INTRODUCTION}

Oil reservoir's recovery process involves three phases: primary, secondary and tertiary recovery.

During primary recovery phase, oil is produced due to natural reservoir energy (compaction drive, solution gas drive, water drive, gas cap drive, gravity drive) with recovery factors of $10-30 \%$. Secondary recovery methods are water or gas injection for reservoir pressure maintenance or/and production increase. Additional recovery factor due to application of these methods is $10-20 \%$. The average recovery factor of current producing oil reservoirs in the world is about $35-40 \%$ (Bonder, 2010) Tertiary methods called 'Enhanced Oil recovery methods' (EOR) are mostly applied in mature oil fields with declining production trend after primary and secondary methods or immediately after primary production phase. These 'Enhanced Oil Recovery' methods (EOR) implies injection of gases or fluids to mobilize residual oil captured in reservoir rock due to presence of strong viscous and capillary forces and high value of interfacial tension between fluid and rock. Recovery increase by these methods can be $15-25 \%$. Oil reservoir's recovery phases with their related recovery factors are presented in Figure 1 (Muggeridge et al, 2014; Zitha et al, 2011).

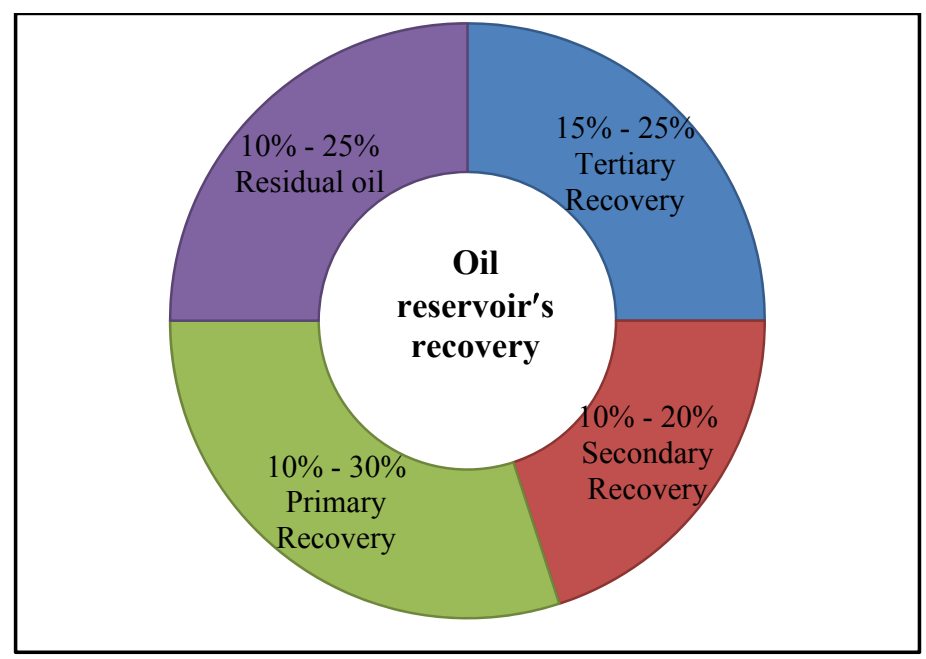

Figure 1 - Oil reservoir's recovery factor 
EOR method's classification according to the type of injected fluid, production mechanism, as well as an approach to process' implementation is presented in Figure 2 (Lake and Walsh, 2008).

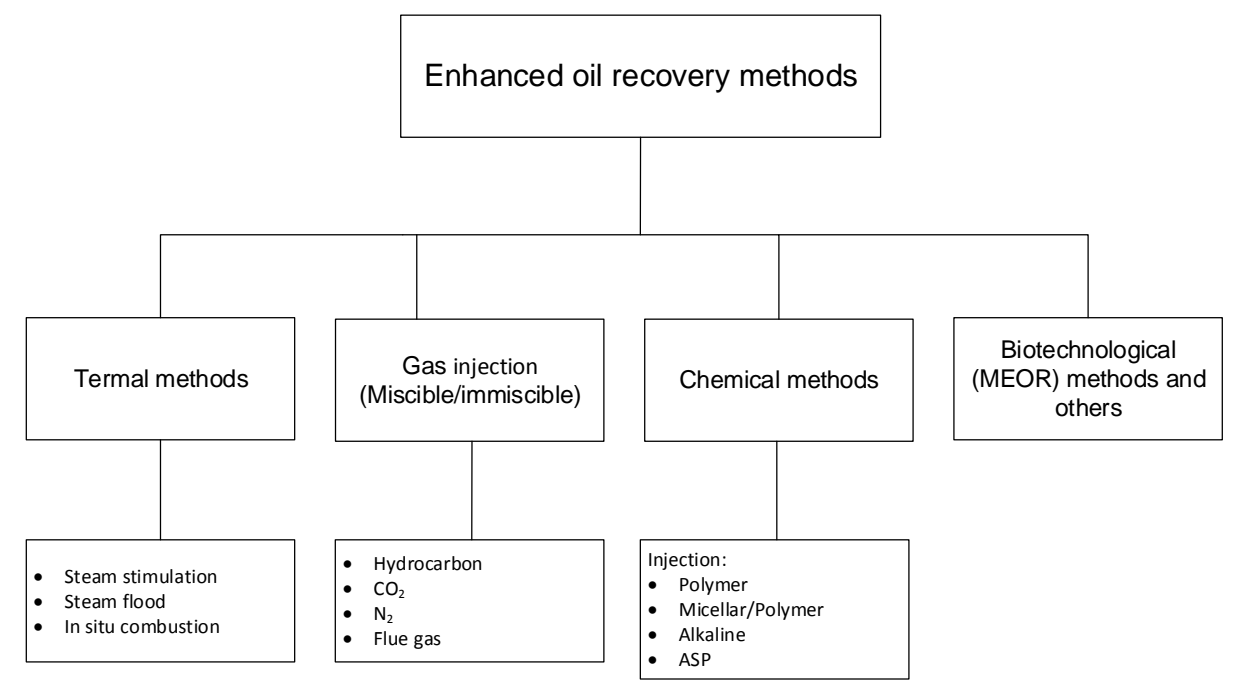

Figure 2 - EOR method's classification

Depending on the specific principles of functioning, EOR methods can be divided into two categories:

1. Methods that improve the efficiency of oil microscopic displacement by fluid injection and

2. methods that improve volumetric sweep efficiency of reservoir by fluid injection (Satter and Thakur, 1994).

The efficiency of oil microscopic displacement represents the ratio of produced oil and oil that is in contact with displacing fluid. This displacement efficiency is under the influence of interfacial tension, wettability, capillary pressure and relative permeability. Oil microscopic displacement efficiency increase is achieved by reducing the oil viscosity (thermal method application) or capillary force/interfacial tension (application of chemical methods-injection of surfactants, alkali or by injection of hydrocarbon gases, $\mathrm{CO}_{2}$ ) (Terry, 2001).

The volumetric (macroscopic) sweep efficiency is the product of vertical and areal sweep efficiency (parts of reservoir area and thickness that are swept by displacing fluid). This efficiency depends on: heterogeneity of the reservoir, mobility ratio of injected fluid and oil, injection and production well's pattern and reservoir rock's characteristics. The macroscopic efficiency of oil displacement is increased by reduction of injected fluid mobility (e.g. injection of polymer aqueous solution) or by increasing the mobility of oil (e.g. thermal methods) (Sydansk and Romero-Zerón, 2011).

EOR methods with conventional secondary recovery methods, stimulating methods (hydraulic fracturing, well treatment by acids and other chemicals), infill 
drilling, horizontal and directional drilling, represents the methods for oil production increase called Improved Oil Recovery - IOR (Hite et al. 2003).

In recent years, world oil production by EOR methods is about 3 million of barrels daily, i.e. about $3.5 \%$ of total daily oil production (www.eia.gov).

Considering that fact, it could be said that EOR methods still have small application despite their good practical results and contribution to oil reservoir's recovery increase. Main reasons for that are: complexity and high cost of EOR project, a long period of implementation and return on investment, the need for multidisciplinary professional team for implementation, the presence of higher risk and uncertainty in comparison to conventional oil production processes.

This paper considers factors influencing the success of implementing EOR projects that include: analysis of EOR processes through the phases of its realization, the price of oil at the world market as the key criteria for justification of EOR method application and the development of new technologies for more efficient process implementation.

\section{PHASES OF EOR PROJECTS' IMPLEMENTATION}

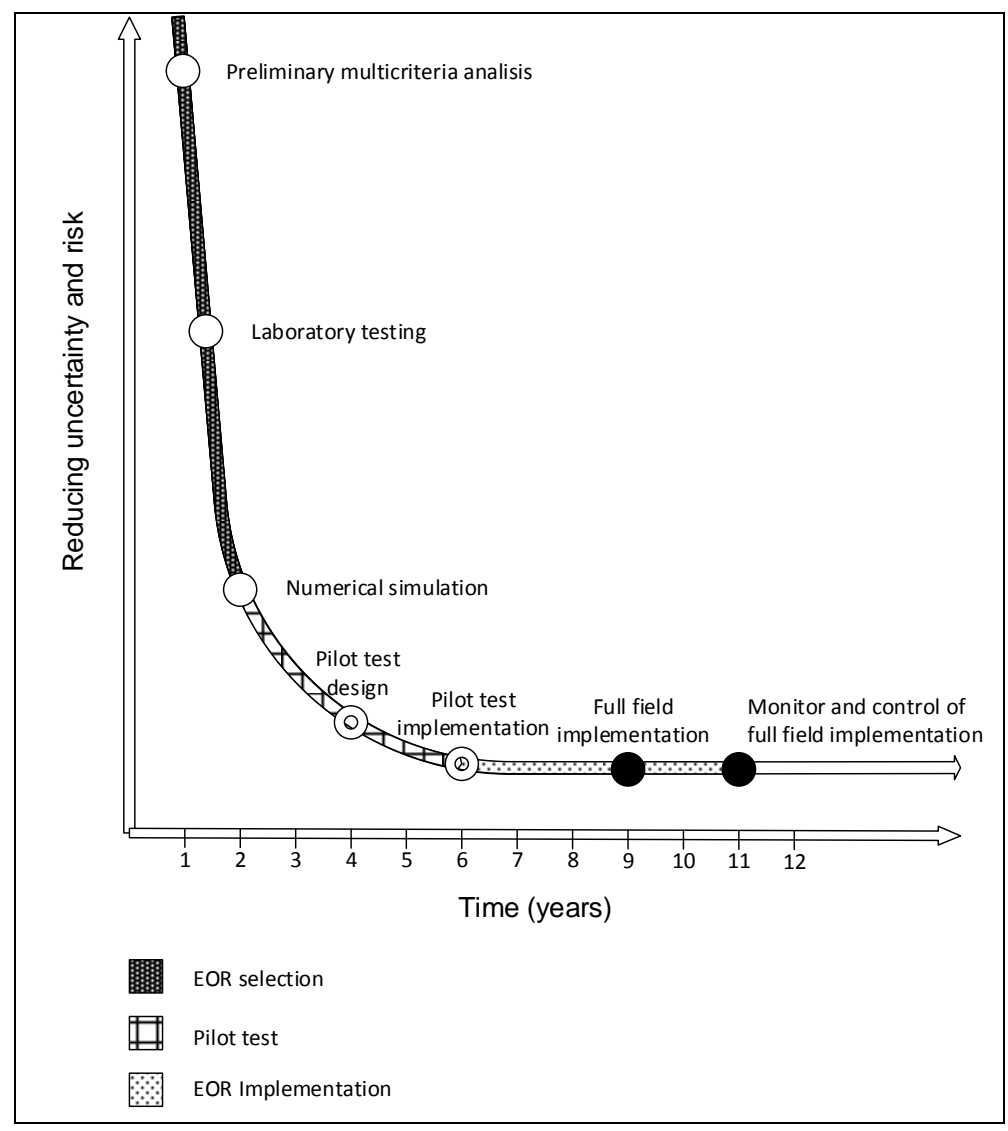

Figure 3 - Phases of EOR projects' implementation 
Implementation of the EOR project is complex and long lasting process comprising the phases shown in Figure 3. In order to achieve a greater level of efficiency and reduction of risks and uncertainties of the project outcome, it is necessary to define the comprehensive management of the EOR process starting from EOR method selection, process designing, performing the pilot test and full implementation at the whole oil reservoir (Gharbi et al. 2012).

Phase 1 refers to the preliminary multi-criteria analysis in order to estimate the possibilities of application of adequate EOR methods at certain oil reservoir. Main properties of fluids and reservoir (potential candidate for the EOR method application), which are comparing to the criteria defined on the basis of laboratory results and practical results of a large number of EOR projects involve: oil viscosity and density, oil saturation, thickness, permeability, porosity, depth, reservoir temperature and pressure, formation type (Trujillo et al. 2010). Screening criteria for EOR processes are given in Table 1 (Terry, 2001). There are different criteria given by several authors in the literature concerning EOR methods. (Taber, 1983; Taber et al. 1997; Goodlett et al. 1986).

Besides parameters in the table, additional criteria and considerations are needed depending on the method which possibility of using is estimated (Karović Maričić et al. 2013).

Table 1 - Screening criteria for EOR processes

\begin{tabular}{|c|c|c|c|c|c|c|c|c|}
\hline EOR process & $\begin{array}{c}\text { Density } \\
{\left[{ }^{\circ} \mathrm{API}\right]}\end{array}$ & $\begin{array}{l}\text { Viscosity } \\
\text { [mPa s] }\end{array}$ & \begin{tabular}{|c|} 
Oil \\
saturation \\
{$[\%]$} \\
\end{tabular} & $\begin{array}{c}\text { Formation } \\
\text { type }\end{array}$ & \begin{tabular}{|c|} 
Net \\
thickness \\
{$[\mathrm{m}]$}
\end{tabular} & $\begin{array}{c}\text { Permea- } \\
\text { bility } \\
{\left[10^{-15} \mathrm{~m}^{2}\right]}\end{array}$ & $\begin{array}{c}\text { Depth } \\
{[\mathrm{m}]}\end{array}$ & $\begin{array}{c}\text { Tempe- } \\
\text { rature } \\
{\left[{ }^{\circ} \mathrm{C}\right]}\end{array}$ \\
\hline \multicolumn{9}{|l|}{ Thermal } \\
\hline $\begin{array}{l}\text { Steam } \\
\text { injection }\end{array}$ & $>10$ & $>20$ & $>40-50$ & $\begin{array}{c}\text { Sand or } \\
\text { sandstone }\end{array}$ & $>3$ & $>50$ & $\begin{array}{l}150- \\
1500\end{array}$ & $\mathrm{NC}$ \\
\hline $\begin{array}{l}\text { In situ } \\
\text { combustion }\end{array}$ & $10-40$ & $<1000$ & $>40-50$ & $\begin{array}{c}\text { Sand or } \\
\text { sandstone }\end{array}$ & $>3$ & $>50$ & $>150$ & $\mathrm{NC}$ \\
\hline \multicolumn{9}{|l|}{ Chemical } \\
\hline Polymer & $>25$ & $5-125$ & $>10$ & $\begin{array}{l}\text { Preferable } \\
\text { sandstone }\end{array}$ & $\mathrm{NC}$ & $>20$ & $<2700$ & $<90$ \\
\hline $\begin{array}{l}\text { Surfactant- } \\
\text { polymer }\end{array}$ & $>15$ & $20-30$ & $>30$ & $\begin{array}{l}\text { Preferable } \\
\text { sandstone }\end{array}$ & $>3$ & $>20$ & $<2700$ & $<90$ \\
\hline Alkaline & $13-35$ & $<200$ & $>10$ & $\begin{array}{l}\text { Preferable } \\
\text { sandstone }\end{array}$ & $\mathrm{NC}$ & $>20$ & $<2700$ & $<90$ \\
\hline \multicolumn{9}{|c|}{ Miscible gas injection } \\
\hline $\begin{array}{c}\text { Hydrocarbon } \\
\text { gas }\end{array}$ & $>35$ & $<10$ & $>30$ & $\begin{array}{c}\text { sandstone } \\
\text { or } \\
\text { carbonate }\end{array}$ & $5-7.5$ & $\mathrm{NC}$ & $>1350$ & $\mathrm{NC}$ \\
\hline $\mathrm{CO}_{2}$ & $>25$ & $<12$ & $>30$ & $\begin{array}{c}\text { sandstone } \\
\text { or } \\
\text { carbonate }\end{array}$ & $5-7.5$ & $\mathrm{NC}$ & $>600$ & $\mathrm{NC}$ \\
\hline $\mathrm{N}_{2}$ & $>35$ & $<10$ & $>30$ & $\begin{array}{c}\text { sandstone } \\
\text { or } \\
\text { carbonate }\end{array}$ & $5-7.5$ & $\mathrm{NC}$ & $>1350$ & $\mathrm{NC}$ \\
\hline
\end{tabular}

*NC-non critical factor 
Further step after the selection of one or more of EOR methods for application in a particular reservoir is conduction of complex reservoir studies involving laboratory testing and development of static geological and dynamic reservoir models. Accurate reservoir model is essential for understanding the behaviour of reservoir fluids and production optimization. Numerical simulators are used for selecting the optimal strategy reservoir' recovery based on prediction of reservoir performance in different production conditions and economic analysis in order to determine the profitability of selected EOR methods. Modelling of all types of EOR techniques such as injection of $\mathrm{CO}_{2}$ and other gases, chemical and thermal processes by 3D simulators provides selecting the optimum EOR techniques for application in reservoir with unique characteristics.

It should be emphasized that a very good understanding of recovery process by selected EOR method is needed for developing an adequate reservoir simulation models, and on that basis to define reliable outcome of EOR process' implementation prediction.

The next stage of the process implementation is designing and implementing the pilot test of selected EOR method at one (mini pilot test) or more wells. Usually, three types of wells are present: injection well for fluid injection, observation well for monitoring and control of critical operating parameters and production well. During the pilot test, a continuous monitoring of production and injection parameters is performed. Also, geophysical well logging in observational wells is done for analysis of oil saturation changes in order to obtain direct estimate of reservoir characteristics as well as insight in injected fluid front's movement. After realization of pilot test, the planning and full implementation of EOR project at the whole reservoir is following. This final stage is based on the results of the pilot test and 'response' of reservoir's part where pilot test has been implemented in the terms of incremental oil production. For EOR project implementation is required 6-10 years, where first phase of selection EOR method, laboratory testing and process modeling lasts 1-2 years, pilot test implementation is 2-4 years, and for application of EOR process in the whole reservoir is required 3-5 years (Bonder, 2010; Schlumberger, 2014).

\section{INFLUENCE OF CRUDE OIL PRICE ON EOR PROCESS REALIZATION}

Beginning and justification of EOR project realization are directly dependent on the crude oil price at the world market. Crude oil price has increased significantly in the period from 2000 until today, with the highest price of $145 \mathrm{USD} /$ barrel in July 2008. The trend of oil prices for 2000 - 2014 period is given in Figure 4 (Investmentmine, 2014).

Recent increase in crude oil prices is mostly affected by geopolitical factor, besides inflation, exchange rate value of the US dollar, great increase in demand and consumption in China, India and other countries with rapid economic development. The geopolitical factor refers to instability in the Middle East, political situation in the Caspian region and Africa, relationships between leading producing countries and includes speculation on the oil stock market. 


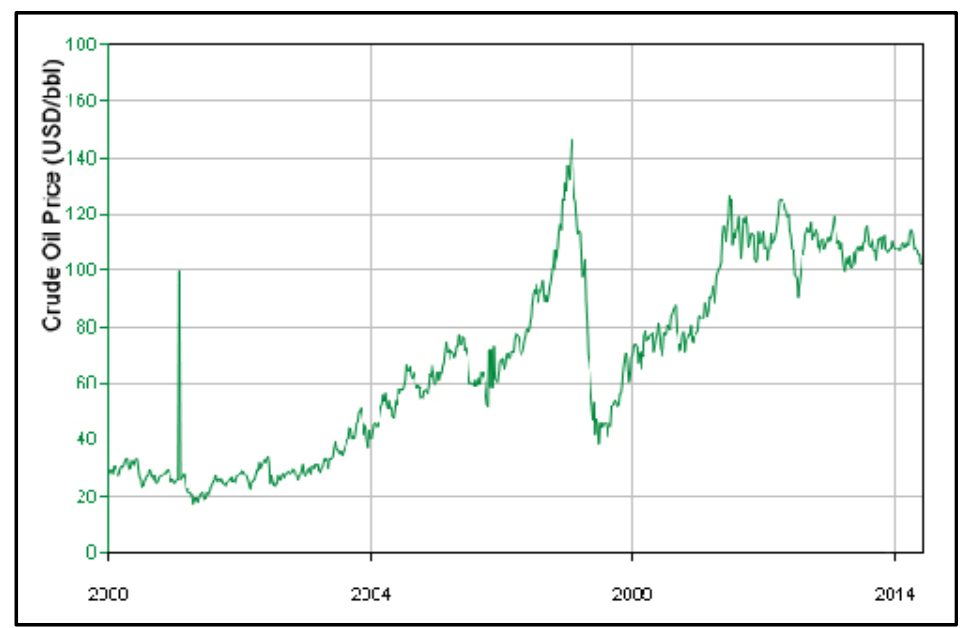

Figure 4 - Crude oil price for 2000 - 2014 period

The analysis of oil price, OPEX and CAPEX of EOR production process where the cost of injected fluids has a largest share, points out that the minimum oil price for the profitable oil production by EOR methods is $60 \mathrm{USD} / \mathrm{barrel}$ (www.eia.gov).

\section{THE EFFECTS OF NEW TECHNOLOGIES ON SUCCESSFUL EOR PROJECT REALIZATION}

During past ten years, significant progress is present in developing new technologies involved in EOR process implementation. Due to the high oil prices and innovative technology, the number of companies interested in EOR projects has been increased. The largest are: BP, Canadian Natural Resources Limited (CNRL), Cenovus Energy Inc., Chevron Corporation, China National Petroleum Corporation (CNPC) (www.visiongain.com).

In the field of thermal methods-stem injection, the most 'popular' process of oil production lately from heavy oil reservoirs is Steam Assisted Gravity Drainage ('SAGD' method).

In the thermal process of oil recovery by in situ combustion, the progress is made in combustion control that has been so far the largest problem for wider use of this method. Also, in situ combustion became applicable to reservoir with lighter oil.

In the field of EOR chemical methods, advance is made by development of new chemicals and a less expensive methods application: thermally stable surfactants and surfactants developed to be active at very low concentration for surfactant flooding, as well as alkaline-polymer (AP) injection and alkaline-surfactant-polymer (ASP) injection (Bonder, 2010).

Process of $\mathrm{CO}_{2}$ injection recently has almost substituted steam injection as the mostly used EOR method in the world. 
The most 'popular' EOR method currently used in the United States and Europe is $\mathrm{CO}_{2}$ injection. This method also presents a promising technology for reducing greenhouse emissions due to development of carbon capture and sequestration technique (CSS). Carbon dioxide by-products from fossil fuel power plants is injected into oil reservoir for enhancing oil recovery. EOR method has an important environmental impact by storing $\mathrm{CO}_{2}$ in deep geological formations (Holloway et al. 2006).

\section{CONCLUSION}

The Enhanced Oil Recovery methods can increase oil reservoir recovery up to $60-70 \%$. There are numerous factors influencing the successful EOR process implementation, starting from fluid and reservoir properties for preliminary selection of EOR method, conducting the laboratory testing, development of accurate reservoir numerical model, pilot test implementation and monitoring to the profitable project's application at the whole reservoir area. Justification of EOR application is directly depending on the crude oil prices at the world market.

The analysis of recent oil prices and expenditures of EOR production process points out that the minimum oil price for profitable oil production by EOR methods is $60 \mathrm{USD} / \mathrm{barrel}$. Increase in crude oil prices at the world market in last decade enables application of these methods. Besides that, very important fact for further intensive application is advancement in developing new technologies involved in EOR process implementation. Modern reservoir numerical simulators, reservoir characterization by 4D seismic survey, horizontal directional drilling, real time monitoring and other new technologies and techniques contribute to more efficient EOR implementation with less risks and uncertainties.

\section{ACKNOWLEDGMENT}

This article is the result of the project financed by the Ministry of Education and Science of Republic of Serbia (Project No. 33001). We thank the ministry for the support.

\section{REFERENCES}

[1] BONDER, P. (2010) EOR-the time is now: Its contribution of world energy supply [Online] Society of Petroleum Engineers. Available from: http://www.spe.org/dl/2010.php [Accessed 10/11/2014].

[2] GHARBI, R. et al. (2012) The Potential of a Surfactant/Polymer Flood in a Middle Eastern Reservoir. Energies, 5 (1), pp 58-70.

[3] GOODLETT, G. O. et al (1986) The Role of Screening and Laboratory Flow Studies in EOR Process Evaluation. In: Proceedings of the SPE Rocky Mountain Regional Meeting, Billings, May 1986. Society of Petroleum Engineers, SPE 15172. 
[4] HITE, J. et al. (2003) IOR and EOR: effective communication requires a definition of terms. Journal of Petroleum Technology, 55 (6), p. 16.

[5] HOLLOWAY, S. et al. (2006) Carbon dioxide transport, injection and geological storage. In: EGGLESTON, S. et al. (eds.) 2006 IPCC Guidelines for National Greenhouse Gas Inventories, Volume 2: Energy. Hayama: Institute for Global Environmental Strategies, pp. 5.1-5.32.

[6] INTERNATIONAL ENERGY AGENCY (2014) World energy outlook 2013 [Online] International Energy Agency. Available from: http://www.worldenergyoutlook.org/publications/weo-2013 [Accessed 10/06/2014].

[7] INVESTMENTMINE (2014) 1 Year Crude Oil Prices and Price Charts [Online] InfoMine. Available from: http://www.infomine.com/investment/ metal-prices/crude-oil/1-year/ [Accessed 20/11/2014].

[8] KAROVIĆ MARIČIĆ, V. et al (2013). The criteria for application of enhanced oil recovery methods [In Serbian]. Energy, economy, ecology, 3-4, pp 173-180.

[9] LAKE, W. L. and WALSH, P. M. (2008) Enhanced oil recovery (EOR) [Technical report]. Austin: Department of Petroleum and Geosystems Engineering, University of Texas at Austin.

[10] MUGGERIDGE, A. et al. (2014) Recovery rates, enhanced oil recovery and technological limits. Philosophical Transactions of the Royal Society A, 372 (2006), pp 1-25.

[11] SATTER, A. and THAKUR, C. G. (1994) Integrated petroleum reservoir management. Tulsa: PennWell Publishing Company.

[12] SCHLUMBERGER (2014) Seizing the EOR opportunity [Online] Schlumberger. Available from: http://www.sbc.slb.com/Our Ideas/ Energy Perspectives/2nd\%20Semester13 Content/ 2nd\%20Semester\%202013 Seizing.aspx [Accessed 10/03/2014].

[13] SYDANSK, R. D. and ROMERO-ZERÓN, L. (2011) Reservoir Conformance Improvement. Richardson: Society of Petroleum Engineers.

[14] TABER, J. J. (1983) Technical Screening Guides for the Enhanced Recovery of Oil. In: Proceedings of the SPE Annual Technical Conference and Exhibition, San Francisco, October 1983. Society of Petroleum Engineers, SPE 12069.

[15] TABER, J. J. et al. (1997) EOR Screening Criteria Revisited - Part 1: Introduction to Screening Criteria and Enhanced Recovery Field Projects. SPE Reservoir Engineering, 12 (3), pp. 189-198.

[16] TERRY, E. R. (2001) Enhanced Oil Recovery. In: MAYERS, A. R. (ed.) Encyclopedia of Physical Science and Technology, Vol.18, 3rd edition. San Diego: Academic press, pp 503-518.

[17] TRUJILLO, M. et al. (2010) Selection Methodology for Screening Evaluation of Enhanced-Oil-Recovery. In: Proceedings of the 2010 LACPEC - SPE Latin American \& Caribbean Petroleum Engineering Conference 'Latin America's Energy Challenge: Sustainable \& Responsible Economic Development', Lima, Decembre 2010. Society of Petroleum Engineers, SPE 139222. 
[18] U.S. ENERGY INFORMATION ADMINISTRATION (n.d.) Annual energy outlook 2014 with projection until 2040 [Online] U.S. Enegry Information Administration. Available from: http://www.eia.gov/forecasts/aeo/pdf/ 0383(2014).pdf [Accessed 10/10/2014].

[19] VISIONGAIN, (2014) The 25 Leading Companies in Enhanced Oil Recovery (EOR) [Online] Visiongain. Available from: https://www.visiongain.com/ Report/1212/The-25-Leading-Companies-in-Enhanced-Oil-Recovery-(EOR)2014 [Accessed 01/11/2014].

[20] ZITHA, P. et al. (2011) Increasing Hydrocarbon Recovery Factors [Online] Society of Petroleum Engineers. Available from: http://www.spe.org/industry/ docs/recoveryfactors.pdf [Accessed 08/09/2014]. 